\title{
Urban mosquito species (Diptera: Culicidae) of dengue endemic communities in the Greater Puntarenas area, Costa Rica
}

\author{
Olger Calderón-Arguedas ${ }^{1}$, Adriana Troyo ${ }^{1,2}$, Mayra E. Solano ${ }^{1}$, Adrián Avendaño ${ }^{1}$ \\ \& John C. Beier ${ }^{2,3}$ \\ 1. Centro de Investigación en Enfermedades Tropicales (CIET), Departamento de Parasitología, Facultad de \\ Microbiología, Universidad de Costa Rica; olger.calderon@ucr.ac.cr \\ 2. Department of Epidemiology and Public Health, Miller School of Medicine, University of Miami, Miami Florida, \\ USA. \\ 3. Abess Center for Ecosystem Science and Policy, University of Miami, Miami, Florida, USA.
}

Received 25-XI-2008. Corrected 03-VI-200. Accepted 07-VII-2009.

\begin{abstract}
Field studies were conducted to determine the mosquito species richness in the urban area of Greater Puntarenas in Costa Rica. Two cross-sectional entomological surveys were performed in seven localities of Puntarenas: one survey was performed during the wet season and the other during the dry season. The sections evaluated were determined by applying a stratified cluster sampling method using satellite imagery, and a sample of 26 cells $(100 \times 100 \mathrm{~m})$ was selected for the study. The number of cells per locality was proportional to the area of each locality. The presence of mosquito larvae and pupae in water-filled artificial and natural containers was determined in each cell. Infestation was expressed as a diversity index per type of container (Ii). Eight types of larvae were identified (Aedes aegypti, Culex quinquefasciatus, Culex interrogator, Culex nigripalpus, Culex corniger, Culex tarsalis, Limatus durhamii and Toxorhynchites theobaldi) and in two cases it was only possible to identify the genus (Culex sp. and Uranotaenia sp.). A. aegypti was the most common species followed by C. quinquefascitus. Diversity of wet environments can explain the co-occurrence of various culicid species in some localities. Although A. aegypti is the only documented disease vector in the area, $C$ quinquefasciatus, $C$. nigripalpus, and the other species of Culex could be considered potential vectors of other pathogens. The presence and ecology of all mosquito species should be studied to optimize surveillance and prevention of dengue and to prevent the emergence of other mosquito-transmitted diseases. Rev. Biol. Trop. 57 (4): 1223-1234. Epub 2009 December 01.
\end{abstract}

Key words: mosquito, Culicidae, dengue, species richness, Puntarenas, Costa Rica.

Mosquitoes are the most important vectors of pathogenic organisms. Diseases like malaria, dengue fever, yellow fever and West Nile encephalitis are transmitted by culicids (Foster $\&$ Walker 2002). In tropical and subtropical countries, dengue is the most important arboviral disease in terms of morbidity and mortality. Some reports estimate dengue incidence at 50 to 100 million cases per year, including 250 000 to 500000 cases of dengue hemorrhagic fever and approximately 24000 deaths (Gibbons \& Vaughn 2002).
In Costa Rica, dengue is the most prevalent vector-borne disease, affecting mainly the North Pacific, Atlantic, and Central Pacific regions. In 2005, there were almost 40000 reported cases (Troyo et al. 2006). Aedes aegyp$t i$ Linnaeus 1762 , which is the main dengue vector, was eliminated from the country in the late 1950s. However, new dengue cases were reported in September of 1993, a few months after the Ministry of Health reported that $A$. aegypti was once again present throughout the country (Guzmán et al. 1998). Since then, 
the larger cities in the North Pacific, Central Pacific, and Atlantic coasts have been the areas most affected by dengue (Troyo et al. 2006).

Puntarenas is one of the cities of Costa Rica where dengue was first reported in 1993 (Guzmán et al. 1998). It is the most important city in the Central Pacific Region, and its economy is based almost entirely on tourist activity and fishing (Abarca-Hernández 2008). This city presents some of the common problems of many larger cities in Latin America: poor urban planning, high unemployment rates, poverty, poor solid waste management, among others (INEC 2002). Its urban and environmental conditions make this city an appropriate environment for the presence of $A$. aegypti and consequently dengue.

The heterogeneity of the urban landscape and its relationship with peri-urban areas can support the occurrence of mosquito species other than A. aegypti (Vargas 1998). On occasion, some mosquito species can share their larval habitats with $A$. aegypti, but there are other species that have very different and more specific habitats for oviposition and larval development. The species richness is defined as the number of species in a community. Species richness and relative abundance are ecological components that can be used to quantify species diversity (Krohne 1998).

The purpose of this investigation was to determine the species richness in localities of Greater Puntarenas. Results from these analyses may be used to estimate risk of transmission of various mosquito borne diseases and optimize local mosquito prevention and control programs (Impoinvil et al. 2007).

\section{MATERIAL AND METHODS}

Puntarenas is located in the Central Pacific Region of Costa Rica ( $09^{\circ} 56^{\prime} 55^{\prime \prime} \mathrm{N}, 84^{\circ} 58^{\prime} 24^{\prime \prime}$ W). It is a peninsula that includes an area of approximately $20 \mathrm{~km}^{2}$, with urban and suburban characteristics (Fig. 1). The elevation of the Greater Puntarenas area is from $0 \mathrm{~m}$ to $15 \mathrm{~m}$. The climate is tropical: mean minimum and maximum daily temperatures are $22^{\circ} \mathrm{C}$ and $32^{\circ} \mathrm{C}$, respectively, and there is a marked wet season (May to mid-November) and a dry season (mid-November to April). The population of the Greater Puntarenas area is close to 100 000 people that live in approximately 20000 houses (INEC 2002).

Two cross-sectional larval surveys were performed to determine the species richness of mosquitoes in seven localities of Greater Puntarenas. One of the surveys was performed during the dry season and the other was carried out in the wet season. The sampling method was a two-step cluster sampling process established in conjunction with seasonal surveys of container profiles, according to the methodology described by Troyo and collaborators (2008a). Briefly, imagery from the Advanced Spaceborne Thermal Emission and Reflection Radiometer (ASTER) and a QuickBird land cover map were used to create the sampling frame by dividing the entire area into a grid with cells of $100 \times 100 \mathrm{~m}$. This cell size was considered optimal since cells would contain $13 \pm 6$ houses for field surveys. Only the 306 cells that had more than $90 \%$ of their area within one specific locality of Puntarenas were included in the sampling frame. This would

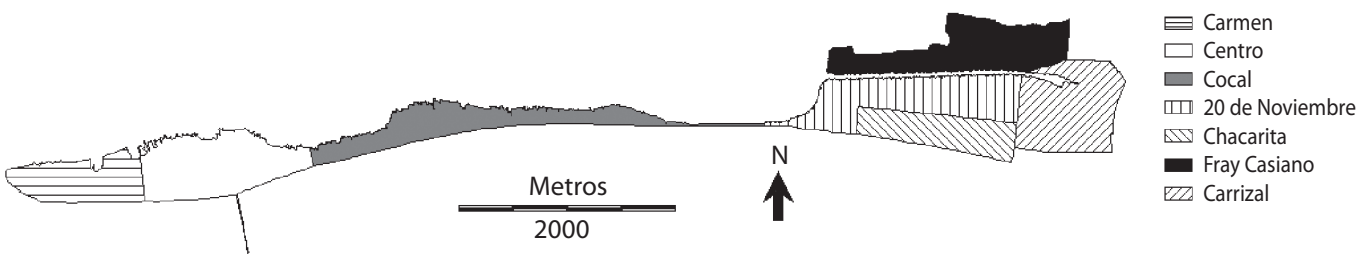

Fig. 1. Localities of the Greater Puntarenas area, Costa Rica. 
guarantee that larval habitats found in a grid cell searched could be considered as belonging to one locality.

Twenty-six cells were selected for the detailed evaluation of species richness and identification of the possible larval habitats. The number of cells surveyed per locality was proportional to the area of each locality. Due to the geographical nature of the sampling method, each of the sampled cells contained different types of locations such as houses, streets, parks, schools, and public areas.

During the surveys, wet habitats that contained culicid larvae and/or pupae were registered, and a sample of mosquito larvae and pupae were transported to the Medical Entomology laboratory at the University of Costa Rica. Entomological material was cleared and mounted in Hoyer's medium for microscopic analysis and identification, which was based on standard taxonomic keys (Dyar 1928, Carpenter \& La Casse 1955, Clark-Hill \& Darsie 1983). This taxonomic information was utilized to determinate the species richness in the Greater Puntarenas area. Data were grouped and organized according to season and locality. The infestation was expressed as a Diversity Index per type of breeding site (Ii) (Bisset et al. 1985), which is defined as:

$$
\mathrm{Ii}=\frac{\mathrm{Ni}}{\mathrm{N}}
$$

Where,

$\mathrm{Ni}=$ Number of breeding sites (of the type of interest) positive for the $i^{\text {th }}$ species

$\mathrm{N}=$ Total number of breeding sites (of the type of interest) positive for any of the species

A database was created in Microsoft Excel( $)$ and imported to Statistix 8 software (Analytical Software), where the statistical analyses were performed. Chi-square tests of homogeneity were performed to evaluate the distribution of frequencies relating positive containers per locality with particular taxa (Daniel 2004).

\section{RESULTS}

Mosquito larvae were detected in each survey. However, the wet season showed the highest percentages of positive locations (Table 1), most of which were houses. However, public and private buildings, as well as urban open spaces like lots, schools, and streets were also positive for habitats containing mosquito larvae (Fig. 2). The species richness was represented by eight species identified as: Aedes aegypti, Culex quinquefasciatus Say 1826, Culex interrogator Dyar \& Knab 1906, Culex nigripalpus Theobald 1901, Culex corniger Theobald 1901, Culex tarsalis Coquillet 1896, Limatus durhamii Theobald 1901 and Toxorhynchites theobaldi Dyar \& Knab 1906 (Table 2). Due to poor condition and insufficient development,

TABLE 1

Positive locations per locality for mosquito larvae according to season

\begin{tabular}{|c|c|c|c|c|}
\hline \multirow{2}{*}{ Locality } & \multicolumn{2}{|c|}{ Dry season } & \multicolumn{2}{|c|}{ Wet season } \\
\hline & Frequency & $\%$ & Frequency & $\%$ \\
\hline Carmen & $6 * / 101 * *$ & 5.9 & $9 / 69$ & 13.0 \\
\hline Centro & $2 / 67$ & 2.9 & $13 / 58$ & 22.4 \\
\hline Cocal & $0 / 40$ & 0.0 & $7 / 35$ & 20.0 \\
\hline Chacarita & $5 / 39$ & 12.8 & $7 / 47$ & 14.9 \\
\hline Fray Casiano & $6 / 90$ & 6.7 & $10 / 48$ & 20.8 \\
\hline 20 de Noviembre & $5 / 44$ & 11.4 & $6 / 54$ & 11.1 \\
\hline Carrizal & $6 / 52$ & 11.5 & $15 / 43$ & 34.9 \\
\hline Total & $30 / 433$ & 6.9 & $67 / 354$ & 18.9 \\
\hline
\end{tabular}



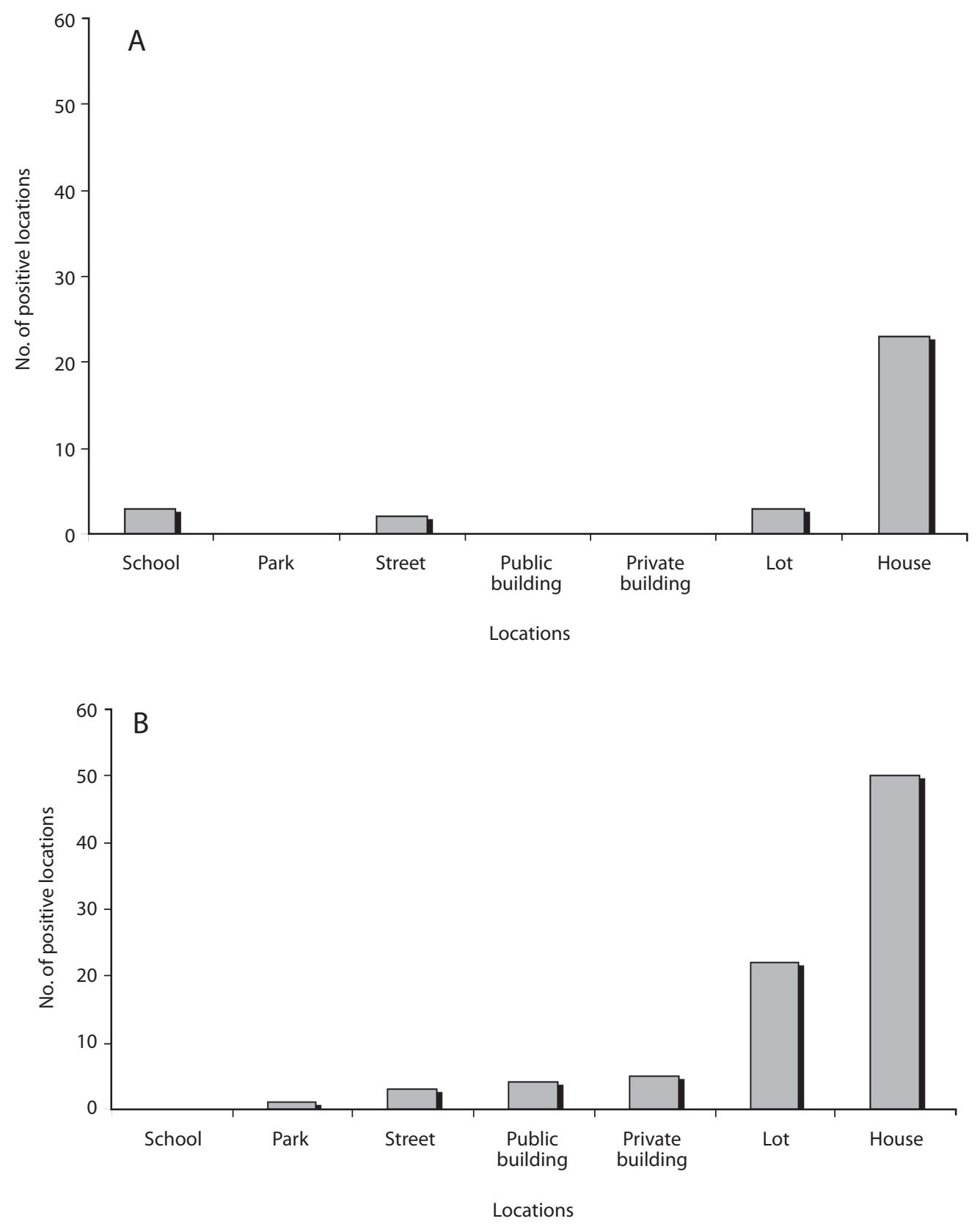

Fig. 2. Types of locations positive for mosquito larvae. a: dry season; b: wet season. 
TABLE 2

Species of mosquito larvae identified according to season

\begin{tabular}{|c|c|c|c|}
\hline Season & Genus & Sub-genus & Species \\
\hline \multirow[t]{7}{*}{ Dry } & Aedes & (Stegomyia) & A. aegypti \\
\hline & Culex & (Culex) & C. quinquefasciatus \\
\hline & & (Culex) & C. tarsalis \\
\hline & & (Culex) & C. coronator \\
\hline & & (Culex) & C. nigripalpus \\
\hline & & (Culex) & C. interrrogator \\
\hline & & (Culex) & Culex sp. \\
\hline \multirow[t]{10}{*}{ Wet } & Aedes & (Stegomyia) & A. aegypti \\
\hline & Culex & (Culex) & C. quinquefasciatus \\
\hline & & (Culex) & C. nigripalpus \\
\hline & & (Culex) & C. interrogator \\
\hline & & (Culex) & C. corniger \\
\hline & & (Culex) & C. coronator \\
\hline & & (Culex) & Culex sp. \\
\hline & Toxorrhynchites & (Linchiella) & T. theobaldi \\
\hline & Limatus & & L. durhamii \\
\hline & Uranotaenia & (Uranotaenia) & Uranotaenia sp. \\
\hline
\end{tabular}

the remaining two types of larvae were identified to genus: Culex sp. and Uranotaenia sp. (Table 2). Overall, A. aegypti was the most frequently collected species in the localities of Greater Puntarenas (Tables 3 and 4). Culex quinquefasciatus was the second most common in terms of occurrence. These two mosquito species were observed in both seasons, but the others were reported only in one of them (Tables 3 and 4). Carrizal was the locality that showed the highest number of locations positive for mosquito larval habitats, and it was also the locality with the greatest richness of mosquito species (Tables 3 and 4).

The distribution of infestation by species among localities did not show homogeneity in either season (dry season: $\chi^{2}=28.71$, $\mathrm{p}=0.53$, d.f. $=30$; wet season: $\chi^{2}=52.12, \mathrm{p}=0.55$, d.f. $=54)$.

The most common habitats containing mosquito larvae were considered permanent and included natural and artificial deposits such as washtubs, roof gutters, puddles, sewers and manholes (Table 4). In this category, gutters and washtubs were frequent sites of larval development. The second most frequent habitat type was the "miscellaneous" category, which included objects like toys, pieces of machinery, cups, shoes, among others, that were usually located outdoors. A. aegypti showed the highest diversity indices for most types of containers evaluated (Table 4).

\section{DISCUSSION}

Mosquitoes are common dipterans in the Greater Puntarenas area (Table 1). The species richness observed in the present study revealed the coexistence of different taxa in a relatively small geographical area (Table 2).

In this area there are variations in the urban environment between localities that promote the occurrence of different mosquito species. These differences are likely to include urban structure, type of vegetation, natural water deposits, and human behavior, which can favor the selection of oviposition sites by particular species of female mosquitoes. Our results showed that the distribution of the infestation between localities was not homogeneous in any of the surveys performed throughout the year. The Western side of Puntarenas, which 


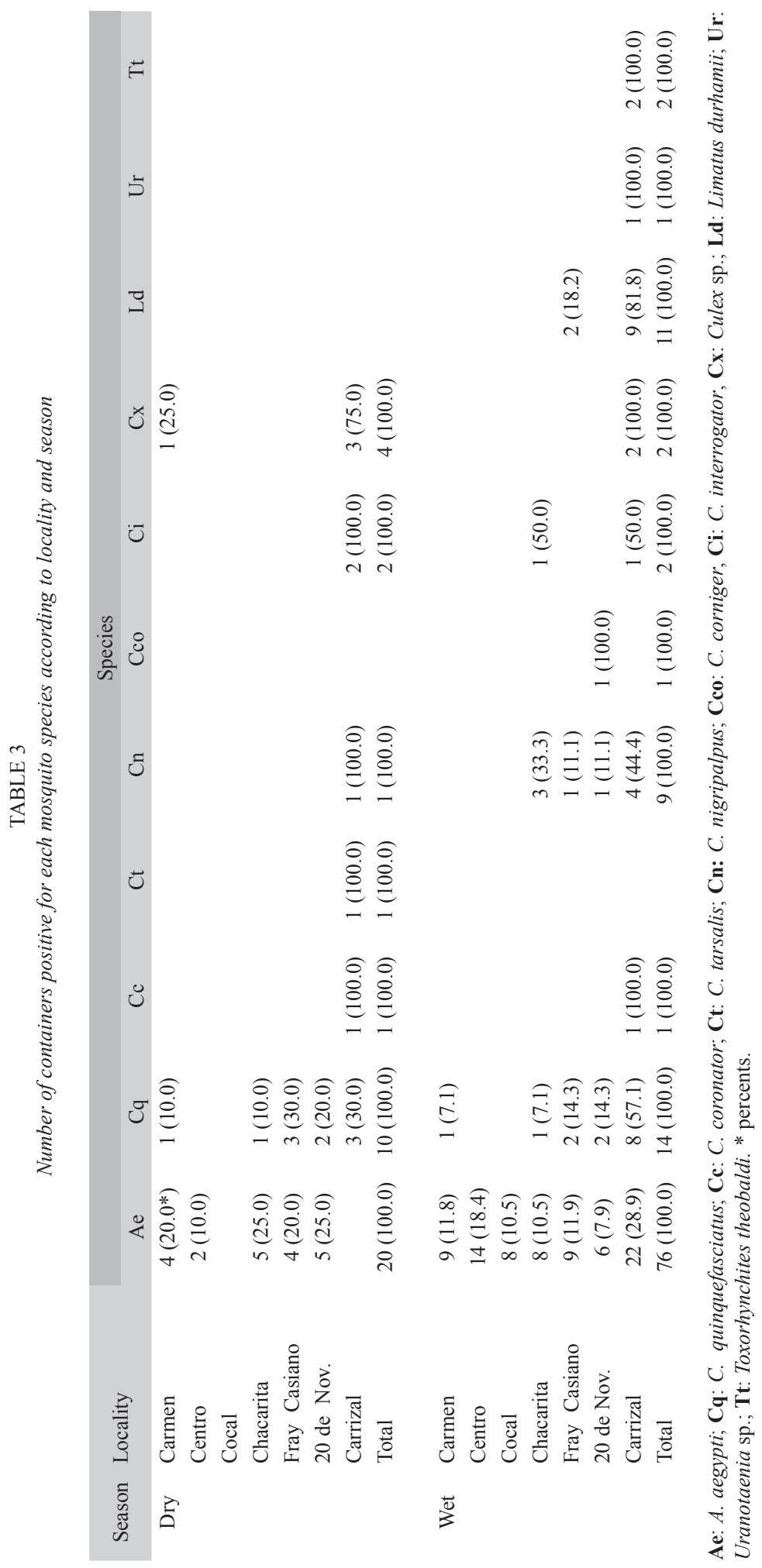




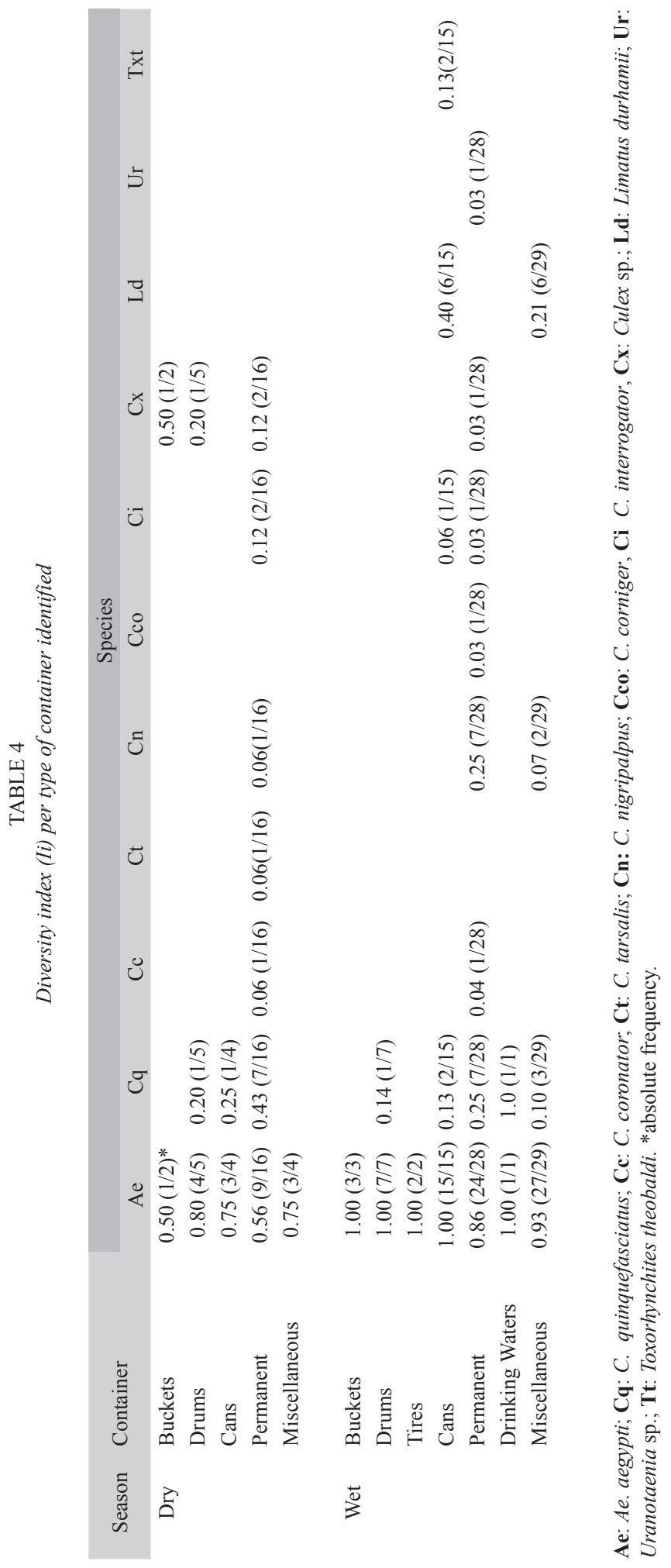


includes the localities of Carmen and Centro, constitutes the urban core of the Greater Puntarenas area (Fig. 1). It shows the traditional landscape of coastal city. In these localities, $A$. aegypti and $C$. quinquefasciatus were the most frequent species found. Although both species were observed during the dry season, higher infestation was documented during the wet season (Table 3). Both A. aegypti and C. quinquefasciatus are very common species in other urban areas of Costa Rica, such as the Central Valley (Calderón-Arguedas 2004, SalazarChang 2005). In coastal cities of other countries where dengue is endemic, $A$. aegypti and $C$. quinquefasciatus, are also the main urban mosquito species found (Bisset et al. 1987).

The majority of the positive habitats identified in the Western section were non-disposable habitats and miscellaneous containers (Table 4), which were located in or around houses. However, there were public spaces and buildings that also contained an important number of larval habitats (Fig. 2). These locations like schools and streets are commonly excluded during entomological surveys, but they can harbor positive water filled containers that help maintain vector populations in endemic areas and can function as a source of mosquitoes that infest nearby areas (Focks et al. 1981, Troyo et al. 2008b).

In the central portion of the Greater Puntarenas area is Cocal. This locality is an isthmus that links the West side of Puntarenas (peninsula) to the East side (Fig. 1). In this locality the density of houses is low in comparison to other localities in the Greater Puntarenas area. This could explain the very low positivity of mosquito larval habitats in Cocal (Table 1). $A$. aegypti was the only species that was documented in this sector. Similar to observations on the west side of Puntarenas, most of the positive habitats were water filled containers associated with households.

The eastern side of the Greater Puntarenas area includes the localities of Chacarita, Fray Casiano, 20 de Noviembre and Carrizal (Fig. 1). In these localities, the landscape is very heterogeneous, where the occurrence of open spaces, non-paved streets, clusters of houses, and several types of vegetation is common. There is also an important diversity in the type of housing, which includes different types of construction, from beach houses to very poor living ranches. Particularly in localities like 20 de Noviembre and Fray Casiano, socioeconomic conditions are variable and there are a few very poor neighborhoods. In these localities, a high $A$. aegypti infestation was reported, mainly in miscellaneous objects located outside the houses (Table 4). These objects probably collected rained water during the wet season and made them adequate sites for oviposition.

In contrast with the Western side of Greater Puntarenas, in the Eastern section most of the positive habitats identified were non-disposable. Within the non-disposable category, gutters were very efficient for maintaining $A$. aegypti larval populations. Gutters represent a real problem, especially since most of the ones observed in Puntarenas were constructed with plastic materials that are easily deformed by environmental conditions like temperature changes. This promotes the accumulation of water and organic debris from vegetation and dust, which makes the conditions ideal for larval development. Additionally, the height of roof gutters does not allow for their continued surveillance by household inhabitants. Similarly to what was observed for the other areas of Puntarenas, other non-disposable deposits like washtubs were important larval habitats in the eastern section of Greater Puntarenas, particularly in the dry season. Washtubs are used by the population to store water in order to facilitate the household labors and not necessarily due to problems with piped water service (Troyo et al. 2008b). These containers were the most common type with $A$. aegypti larvae in the dry season, and they are probably responsible for maintaining $A$. aegypti populations during drier months. In a study performed in the locality of "El Progreso", Honduras, washtubs were also important deposits that promoted the development of $A$. aegypti larvae (Leonstini et al. 1993). Together, washtubs and gutters could explain the permanence of $A$. aegypti during 
the entire year in the Puntarenas area, which may allow the occurrence of dengue cases in both dry and wet seasons.

In the eastern localities of Puntarenas, as was described for the western localities, many positive containers were associated with houses, but an important number was also associated with non-household settings like lots, streets and public spaces. A previous study in the Puntarenas area determined that the eastern localities have higher NDVI (normalized difference vegetation index) values, which could be explained by the abundance of trees and open spaces covered by grasses and small vegetation (Troyo et al. 2009).

Other culicid species like $L$. durhamii were present in some of the open spaces evaluated such as parks, streets, and lots of the eastern section of Puntarenas. The larvae of $L$. durhamii resemble those of $A$. aegypti when observed by the naked eye, and this can complicate the calculation of aedic indices during dengue surveillance when identification is performed without magnifying devices. In addition, $L$. durhamii larvae have shown a facultative predatory activity when nutritional resources are scarce (Lopes 1999), and this is probably the reason why this species was mostly found sharing the habitat with other mosquito species like $A$. aegypti, $C$. quinquefasciatus and other species of Culex (Table 3).

In terms of diversity, Carrizal was the locality that showed the highest mosquito diversity (Tables 1 and 2). In Carrizal, the landscape includes small clusters of houses as well as open spaces, where the occurrence of natural water deposits like small lakes, swamps, and streams is common. In this locality, A. aegypti was observed only during the wet seasons, when the general abundance of this species is estimated to be very high. In addition to $A$. aegypti and $C$. quinquefasciatus, there were other species observed in Carrizal: C. coronator, C. tarsalis, C. nigripalpus, $C$. interrogator, C. sp., L. durhamii, T. theobaldi and Uranotaenia sp. Most of these species had been documented in a study performed in the irrigation project of Arenal-Tempisque, located in communities of the Guanacaste Province (Vargas \& Vargas 2003). C. coronator, C. corniger, L. durhamii, T. theobaldi and Uranotaenia have also been reported in the Central Valley of Costa Rica (Calderón-Arguedas et al. 2004, Salazar-Chang 2005).

The analysis of the diversity per type of breeding site demonstrates that $A$. aegypti show high values for the diversity index in nearly all categories of containers (Table 4). In these sense $A$. aegypti is the dominant culicid in the area, and the treatment or elimination of these water filled containers are required for its control. The other species of mosquitoes show low values of the diversity index for particular types of containers (Table 4). With the exception of C. quinquefasciatus, these species are usually associated with ecological environments different from those found in urban areas but can occasionally be found in urban ecosystems like the one studied. Therefore, having different species of mosquitoes coexisting in the urban environment suggests that different strategies are needed to control nuisance mosquitoes and potential vectors of human diseases.

The role of $A$. aegypti as the vector of dengue has been documented in the Greater Puntarenas area. A previous study demonstrated that rainfall is associated with increases in dengue cases in Puntarenas. Also, the abundance of $A$. aegypti usually increases in the wet season, which is reflected in the higher values of the traditional larval indices for A. aegypti (Troyo et al. 2008b).

Although C. quinquefasciatus has not been associated with the transmission of any vectorborne disease in Puntarenas, it has been demonstrated that $C$. quinquefasciatus can feed from both birds and humans, an ideal behavior for the transmission of West Nile Virus (Zinser et al. 2004). Therefore, the high prevalence of this species in the area may increase the risk of West Nile Virus transmission. Of the other culicid species found in Puntarenas, $C$. nigripalpus and $C$. tarsalis have also been associated with transmission of West Nile virus (Mores et al. 2007, Reisen et al. 2006), as well as other viral encephalitis, specifically 
Saint Louis encephalitis for C. ningripalpus and Eastern equine encephalitis for $C$. tarsalis (Kramer 2001). However, there is currently no information about the possible role that these species may play in the transmission of these arbovirosis in Costa Rica.

T. theobaldi, is a predator species in the larval stage, and the fact that the adults do not ingest blood have made it a candidate for biological control of other mosquito species (Lopes et al. 1993). Since T. theobaldi and $L$. durhamii show predatory activity, their role as ecological modulators of other culicid populations warrants further investigation.

The analysis of each vector as a particular vector of pathogens in Puntarenas and in the rest of the country requires additional evaluation. Although $A$. aegypti is currently the main focus of health authorities, these biodiversity results in Greater Puntarenas demonstrate that the current mosquito control programs should include surveillance of all culicid species present in order to understand the potential risk for transmission of additional mosquito-borne diseases in the area. Moreover, it should be clear that the larval habitats that are targeted during control of $A$. aegypti will not consistently and uniformly affect the abundance of other culicids. When the abundance of $A$. aegypti is low, reinfestation by other mosquito species and nuisance biting can be perceived by people as a fail in the $A$. aegypti control. Therefore all species present and the different strategies required should be considered when developing mosquito control measures.

\section{ACKNOWLEDGMENTS}

The authors will like to express their gratitude to the people of Puntarenas and the local Ministry of Health; to Lissette Retana, Nelson Mena, Iván Coronado, Adriana Duarte, Julio Rojas, and Christian Fonseca for their cooperation during the field surveys. This research was supported by the Vicerrectoría de Investigación, Universidad de Costa Rica projects
VI-803-A6-401 and VI 803-A6-039. It was also supported in part by NIH Grant Number P20 RR020770. John C. Beier also acknowledges financial support from the Abess Center for Ecosystem Science and Policy, University of Miami.

\section{RESUMEN}

La riqueza de especies de mosquitos urbanos de la Gran Puntarenas (Puntarenas, Costa Rica) fue evaluada por medio de análisis larvales. Dos encuestas entomológicas fueron realizadas en siete localidades de la Gran Puntarenas durante un año. Una de las encuestas fue realizada en la estación seca y la otra se llevó a cabo en la estación lluviosa. Las áreas evaluadas fueron determinadas aplicando un muestreo por conglomerados usando imágenes satelitales. Veintiséis celdas $(100 \times 100 \mathrm{~m})$ fueron seleccionadas en las comunidades elegidas y en éstas fueron realizadas las evaluaciones entomológicas. El número de celdas por localidad fue proporcional al área de cada localidad. La presencia de larvas o pupas fue determinada en contenedores con agua (naturales y artificiales). La infestación se expresó por medio índices de diversidad por tipo de contenedor (Ii). La asociación entre contenedores positivos por especies particulares y localidades fue evaluada mediante pruebas de Chi-cuadrado $(\alpha=0.05)$. Ocho de los tipos de larvas encontrados fueron identificados a nivel de especie (Aedes aegypti, Culex quinquefasciatus, C. interrogator, C. nigripalpus, C. corniger, C. tarsalis, Limatus durhamii, Toxorhynchites theobaldi) y dos se identificaron a nivel de género (Culex sp., y Uranotaenia sp). A aegypti fue la especie más frecuente en la Gran Puntarenas. C. quinquefasciatus fue la segunda en frecuencia. Algunas localidades como Carrizal mostraron una importante diversidad de ambientes acuáticos que promovieron la ocurrencia de diferentes especies de culícidos. La distribución de los contenedores positivos por localidad en función de las especies encontradas no mostró homogeneidad ( $\mathrm{p}>0.05)$. Aunque $A$. aegypti es el único vector documentado en la zona, otros mosquitos como $C$. quinquefasciatus y otras especies de Culex podrían ser potenciales vectores de otros agentes etiológicos (virus del Nilo occidental, virus de la encefalitis de San Luis, virus de la encefalitis equina del este). Los resultados obtenidos indican la necesidad considerar la presencia y la ecología de todas las especies de mosquitos en las campañas preventivas por dengue en el área, y en la vigilancia epidemiológica por otras enfermedades transmitidas por mosquitos.

Palabras Clave: mosquito, Culicidae, dengue, riqueza de especies, Puntarenas, Costa Rica. 


\section{REFERENCES}

Bisset, J.A., M.C. Marquetti, M.E. Mendizábal \& A. Navarro. 1985. La abundancia larval de mosquitos urbanos durante la campaña de erradicación del A. aegypti (Linnaeus, 1762) y del dengue en Cuba (1981-82). Rev. Cub. Med. Trop. 37: 161-168.

Bisset, J.A., M.C. Marquetti, B. González, M.E. Mendizábal \& A. Navarro-Ortega. 1987. Algunos aspectos del nicho ecológico de Aedes (S.) aegypti Linnaeus, 1762 (Diptera: Culicidae) y Culex (C.) quinquefasciatus Say, 1823 (Diptera: Culicidae) en el ambiente urbano. Rev. Cub. Med. Trop. 39: 113-118.

Calderón-Arguedas, O., A. Troyo \& M.E. Solano. 2004. Diversidad larval de mosquitos (Diptera: Culicidae) en contenedores artificiales procedentes de una comunidad urbana de San José, Costa Rica. Parasitol. Latinoam. 59: 132-136.

Carpenter, S.J. \& W.J. LaCasse. 1955. Mosquitoes of North America (North of Mexico). University of California Press, California, USA.

Clark-Gil, S. \& R.F. Darsie. 1983. The mosquitoes of Guatemala; their identification, distribution and bionomics, with keys to adult females and larvae. Mosquito Systematics 15: 151-284.

Daniel, W. 2004. Bioestadística: Base para el análisis de las ciencias de la salud. Limusa-Wiley, Mexico D.F., Mexico.

Dyar H.G. 1928. Genus Limatus Theobald, p. 24-27. In The mosquitoes of the Americas. Carnegie Institution of Washington. Publication No. 387, Washington, D.C. USA.

Focks, D.A., S.R. Sackett, D.L. Bailey \& D.A. Dame. 1981. Observations on container-breeding mosquitoes in New Orleans, Louisiana, with an estimate of the population density of $A$. aegypti. Am. J. Trop. Med. Hyg. 30: 1329-1335.

Foster, W.A. \& E.D. Walker. 2002. Mosquitos (Culicidae). In Mullen G. \& Durden L. (eds.). Medical and Veterinary Entomology. Academic, California, USA

Gibbons, R.V. \& D.W. Vaughn. 2002. Dengue: an escalating problem. Br. Med. J. 324: 1563-1566.

Guzmán, M.G., G. Huelva, E. Sáenz, E. Quiroz, J. de los Reyes, A. Balmaseda, A. González \& G. Kouri. 1998. Reintroducción del dengue tres en las Américas: 1994-1996. Arch. Venez. Med. Trop. 2: 8-19.

Impoinvil, D., E.S. Ahmad, A. Troyo, J. Keating, A.K. Githeko, C.M. Mbogo, L. Kibe, J.I. Githure, A.M.
Gad, A.N. Hassan, L. Orshan, A. Warburg, O. Calderón-Arguedas, V.M. Sánchez-Loría, R. Velit-Suarez, D.D. Chadee, R.J. Novak \& J.C. Beier. 2007. Comparison of mosquito control programs in seven urban sites in Africa, the Middle East, and the Americas. Health Policy 83: 196-212.

INEC (Instituto Nacional de Estadística y Censos). 2002. V Censo Nacional de Vivienda. INEC, San José, San José, Costa Rica.

Kramer, L.D. 2001. St Louis encephalitis, p. 448-454. In M.W. Sevice (ed.). The encyclopedia of arthropodtransmitted infections. Cabi, Wallingford, Oxon, UK.

Krohne, D.T. 1998. General ecology. Wadsworth, Belmont, California, USA.

Leonstsini, E., E. Gil, C. Kendall \& G. Clark. 1993. Effect of a community-based Aedes aegypti control programme on mosquito larval production sites in El Progreso, Honduras. Trans. Roy. Soc. Trop. Med. Hyg. 87: 267-271.

Lopes, J. 1999. Ecologia de mosquitos (Diptera: Culicidae) em criadouros naturais e artificiais de área rual no norte do estado do Paraná, Brasil. Influencia das larvas predadoras (Toxorhynchites sp, Limatus durhamii e Culex bigoti) sobre populacao de larvas de Culex quinquefasciatus e Culex eduardoi. Rev. Bras. Zool. 16: 821-826.

Lopes J., M.A.N. da Silva, A.M. Borsal, V.D.R.B. de Oliveira \& F.J. de Oliveira. 1993. Aedes (Stegomyia) aegypti L. e a culicideofauna associada em área urbana da regiao sul, Brasil. Rev. Saúde. Pub. 27: 326-333.

Mores, C.N., M.J. Turell, D.J. Dohm, J.A. Blow, M.T. Carranza \& M. Quintana. 2007. Experimental transmission of West Nile Virus by Culex nigripalpus from Honduras. Vector-Borne Zoonot. 7: 279-284.

Reisen, W.K., Y. Fang \& V.M. Martínez. 2006. Effects of temperature on the transmission of West Nile virus by Culex tarsalis (Diptera: Culicidae). J. Med. Entomol. 43: 309-317.

Salazar-Chang, H. 2005. Infestación de Smittium culisetae (Trichomycetes) en larvas de mosquitos (Diptera: Culicideae) en el Valle Central de Costa Rica. Revista Costarricense de Ciencias Médicas 26: 26-31.

Troyo, A., D.O. Fuller, O. Calderón-Arguedas, M.E. Solano \& J.C. Beier. 2009. Urban structure and dengue fever in Puntarenas, Costa Rica. Singapore J. Trop. Geogr. 30: 265-282. 
Troyo, A., D.O. Fuller, O. Calderón-Arguedas \& J.C. Beier. 2008a. A geographical sampling method for surveys of mosquito larvae in an urban area using high-resolution satellite imagery. J. Vector Ecol. 33:1-7.

Troyo, A., O. Calderón-Arguedas, D.O. Fuller, M.E. Solano, A. Avendaño, K.L. Arheart, D.D. Chadee \& J.C. Beier. 2008b. Seasonal profiles of Aedes aegypti (Diptera: Culicidae) larval habitats in an urban area of Costa Rica with history of mosquito control. J. Vector Ecol. 33: 76-88.

Troyo, A., S.L. Porcelain, O. Calderón-Arguedas, D.D. Chadee \& J.C. Beier. 2006. Dengue in Costa Rica: the gap in local scientific research. Rev. Panam. Salud Pública. 20: 350-360.

Vargas, M. \& J.V. Vargas. 2003. Male and mosquito larvae survey at the Arenal-Tempisque irrigation project, Guanacaste, Costa Rica. Rev. Biol. Trop. 51: 759-762.
Vargas, M. 1998. El mosquito: un enemigo peligroso. Universidad de Costa Rica, San Pedro, San José, Costa Rica.

Zinser, M., F. Ramberg \& E. Willot. 2004. Culex quinquefasciatus (Diptera: Culicidae) as a potential West Nile Virus vector in Tucson, Arizona: blood meal analysis indicates feeding on both human and birds. J. Insect. Sci. 4: 20

\section{INTERNET REFERENCES}

Abarca-Hernández, O. 2008. Datos históricos, económicos y sociales sobre el Cantón de Puntarenas. En ocasión del 150 aniversario de la ciudad. Universidad de Costa Rica, Puntarenas, Costa Rica (Consulted: November $7^{\text {th }}$, http://www.srp.ucr.ac.cr/aniverpuerto_01.html). 